\title{
ACCUMULATION DISTRIBUTION IN THE IAGP AREA,
}

\section{ANTARCTICA: $90^{\circ} \mathrm{E}-150^{\circ} \mathrm{E}$}

by

\author{
N. W. Young,
}

(Antarctic Division, Kingston, Tasmania 7150, Australia)

\section{Pourchet,}

(Laboratoire de Glaciologie et Géophysique de l'Environnement, 2 rue Très-Cloîtres, 38031 Grenoble Cedex, France)

\author{
V. M. Kotlyakov and P. A. Korolev \\ (Institute of Geography, Academy of Sciences U.S.S.R., Staromonetny per. 29, \\ Moscow 109017, U.S.S.R. \\ and M. B. Dyugerov \\ (Department of Geography, Moscow State University, Moscow 117234, U.S.S.R.)
}

\section{ABSTRACT}

The distribution of mean net accumulation rate over a large sector $\left(90^{\circ} \mathrm{E}\right.$ to $\left.150^{\circ} \mathrm{E}\right)$ of the IAGP (International Antarctic Glaciological Project) area in Antarctica is presented in map form. The basic data have been compiled from direct measurements of accumulation at stake networks, and by dating horizons in the snow pack by gross $\beta$-activity measurements, on four long traverse routes. The spatial variability can be high, over $40 \%$, for a single year, and typically about $20 \%$ for multiyear averages. Local surface topography in the form of undulations of several kilometres wavelength can account for about $35 \%$ of the variance. Averaging over intervals of $50 \mathrm{~km}$ or more will give the smooth large-scale distribution pattern. But the resultant values can still deviate from the long-term average accumulation by $25 \%$ or more due to temporal variability over time scales of years to decades.

A very high correlation $(r=0.97)$ was found for the relationship $a=1414 \exp (0.060 \theta)$ between accumulation, a $\mathrm{kg} \mathrm{m}^{-2} \mathrm{a}^{-1}$, and $10 \mathrm{~m}$ depth snow temperature, $\theta{ }^{\circ} \mathrm{C}$, when the data set was limited to a single large drainage basin in Wilkes Land.

\section{INTRODUCTION}

The net snow accumulation at a point is a result of the redistribution and modification of precipitation by surface winds and other processes. Bul1 (1971) collated and summarized available accumulation data to 1970 for all of Antarctica, and discussed the various methods used to collect the data. Much of the data was obtained by stratigraphic studies with its inherent difficulties in determining sequential annual layers in low accumulation areas, and the remainder by observations at stake networks or by other methods. The data coverage was very sparse over a large sector of East Antarctica between $45^{\circ} \mathrm{E}$ and $140^{\circ} \mathrm{E}$. Kotlyakov and others (1974) updated the accumu- lation map with the addition of more recent data, principally the results from stake measurements along the Mirny to Vostok route (Barkov 1974) and data from the traverse inland of Molodezhnaya.

This paper contains up-to-date data for the primary IAGP area between longitudes $90^{\circ} \mathrm{E}$ and $150^{\circ} \mathrm{E}$. New accumulation data from stake networks and gross B-activity measurements are available along four major traverse routes in the region:

1. Mirny to Vostok,

2. Pionerskaya to Dome C,

3. Casey to Vostok (to $840 \mathrm{~km}$ )

4. Dumont d'Urville to Dome $C$ (to $800 \mathrm{~km}$ ).

A map has been compiled for the area using selected available data. The measurement and areal variability of the accumulation rate is discussed using results from regularly spaced stakes, at approximately $2 \mathrm{~km}$ intervals, along the routes. The temporal variability of the annual accumulation increment is investigated using data from stakes, where measurements over a number of years are available, and from $\beta$-activity and other studies. A reported $30 \%$ increase in accumulation rate for the 1965-75 decade, compared to the preceding decade, for a large sector of Antarctica (Pourchet and others in press) is considered in this context.

\section{ACCUMULATION DATA}

Mirny to Vostok

Measurements of snow accumulation have been made at regularly spaced stakes along the Mirny to Vostok route since 1970 . Barkov (1974) reported measurements of surface snow density and mean annual accumulation rate for the four years 1970 to 1973 at stakes grouped over $10 \mathrm{~km}$ intervals. Stakes were situated at approximately $2 \mathrm{~km}$ intervals over most of the route. Gordiyenko and others (1980) include measurements at this same network, to Vostok I $\left(72^{\circ} 09^{\prime} \mathrm{S}, 96^{\circ} 37^{\prime} \mathrm{E}\right)$, for the period 1973 to 1978 in a summary of results 
of isotopic and chemical analyses along the route. Accumulation rates determined by $B$-activity, $\mathrm{Pb}^{210}$, $\delta^{18} 0$, stratigraphic and stake measurements are compared for a number of sites.

Pionerskaya to Dome $C$

A network of stakes was established along the new route $670 \mathrm{~km}$ (GM13) from Pionerskaya in 1977 and extended to Dome $C$ in 1978. The network has been remeasured each year to 1981 . Measurements of surface snow density have been analysed and summarized by Dyugerov and Korolev (1980) for the section to 670 $\mathrm{km}$. Additional networks of 20 stakes, each at $100 \mathrm{~m}$ spacing on four orthogonal arms centred on a snow stratigraphy pit, are situated at regular intervals along the route.

Casey to Vostok (to $840 \mathrm{~km}$ )

oversnow traverses were made along the route to $290 \mathrm{~km}$ south of $\$ 2\left(66^{\circ} 30^{\prime} \mathrm{S}, 112^{\circ} 13^{\prime} \mathrm{E}\right)$, in 1960 , to $480 \mathrm{~km}$ in 1961 , and to Vostok in 1962. Stake measurements were made to $480 \mathrm{~km}$ at approximately $1.6 \mathrm{~km}$ intervals (Black and Budd 1964, Battye unpublished). A new network was established at $2 \mathrm{~km}$ intervals from about $69^{\circ} \mathrm{S}$ (V 100) to $840 \mathrm{~km}$ (V 680) south of S2 in 1978 and was remeasured in 1979 (Sheehy unpublished). Surface snow-density measurements and other data have been reported by Battye (unpublished) and Budd (1966). Dumont d'Urville to Dome C (to $800 \mathrm{~km}$ )

oversnow traverses were made intand from Dumont d'Urville $800 \mathrm{~km}$ towards Dome $\mathrm{C}$ in 1971-72 and in 1972-73. Samples were collected at a number of points along the traverse route for the determination of accumulation rate by gross $\beta$-activity measurements (Lambert and others 1977). Further samples were collected on later traverses in 1976 and 1977 (Pourchet and others in press).

\section{PROBLEMS ASSOCIATED WITH DATA INTERPRETATION}

Measurements of net snow accumulation exhibit considerable variability on spatial scales of metres to kilometres and temporal scales of one to many years. This variability needs to be considered when interpreting the data for particular applications. Spatial variability

Barkov (1974) presents the variability of the 4 a mean accumulation at stakes grouped in $10 \mathrm{~km}$ intervals. The values of the coefficient of variability (ratio of standard deviation to group mean) are generally in the range of $10 \%$ to $30 \%$, typically less than $20 \%$, and up to $60 \%$ for a few cases. The highest variability occurs in a region about $250 \mathrm{~km}$ inland of Mirny where the accumulation rate is anomalously low compared to the neighbouring areas.

The mean accumulation at stakes along the Pionerskaya to Dome C line exhibited a very similar pattern of variability to that reported by Barkov (1974) when grouped in $10 \mathrm{~km}$ intervals. When grouped in $50 \mathrm{~km}$ intervals the variability ranged between $20 \%$ and $30 \%$, with standard deviations from 0.7 to $5.0 \mathrm{~kg} \mathrm{~m}^{-2} \mathrm{a}^{-1}$. For a single annual increment, the variability ranged from $40 \%$ to over $100 \%$, and was typically between $50 \%$ and $70 \%$ for both the Pionerskaya to Dome $C$ and the Casey to Vostok routes. Whillans (1978) ascribes a variability of $20 \mathrm{~kg} \mathrm{~m}^{-2} \mathrm{a}^{-1}$ due to surface microrelief (effects of sastrugi, etc.) to his results from stake measurements on the $160 \mathrm{~km}$ long Byrd station net (average accumulation $150 \mathrm{~kg} \mathrm{~m}^{-2} \mathrm{a}^{-1}$ ). Relationship with topography

The Targe-scale features of the accumulation distribution are controlled by meteorological parameters and orographic factors which explain, for instance, the general decrease of accumulation from the coast (up to $900 \mathrm{~kg} \mathrm{~m}^{-2} \mathrm{a}^{-1}$ ) to the high Antarctic plateau (less than $30 \mathrm{~kg} \mathrm{~m}^{-2} \mathrm{a}^{-1}$ ) (Lorius in press). Local topographic features can introduce considerable variability into the large-scale pattern. Surface undulations of wavelength 5 to $15 \mathrm{~km}$, caused by the bedrock topography and local accumulation pattern, are present over large areas of the ice sheet (Young and others 1982). Black and Budd
(1964) reported regular variations in the accumulation rate over a number of surface undulations inland of Casey. They found an average variation over an undulation of $\pm 170 \mathrm{~kg} \mathrm{~m}^{-2} \mathrm{a}^{-1}$ in an average net accumulation of $630 \mathrm{~kg} \mathrm{~m}^{-2} \mathrm{a}^{-1}$ for average changes in slope of \pm 0.015 along a $45 \mathrm{~km}$ line. Whillans (1975) reported a variability of $\pm 10 \mathrm{~kg} \mathrm{~m}^{-2} \mathrm{a}^{-1}$ for slope changes of about \pm 0.001 along a line of $120 \mathrm{~km}$ length.

A similarly varying pattern of accumulation with surface topography was found in the interior of the ice sheet along the Casey to Vostok and the Pionerskaya to Dome $C$ routes. The correlation of the variations in accumulation with those in topography varied along the route with the relative orientation of the mean wind with respect to the traverse direction. The direction of the mean wind is determined by the largescale surface slope. A preliminary investigation of this behaviour for a $200 \mathrm{~km}$ segment of the $P$ ionerskaya to Dome $C$ line (Fig.1) gave the following relation for the variation of accumulation:

$$
\begin{aligned}
\Delta \mathrm{a} & =-0.39 \mathrm{~h}-1.34 \mathrm{~s} \quad \mathrm{~kg} \mathrm{~m}^{-2} \mathrm{a}^{-1} \\
\text { or } \frac{\Delta \mathrm{a}}{\sigma_{\mathrm{a}}} & =-0.021 \frac{\mathrm{h}}{\sigma_{\mathrm{h}}}-0.312 \frac{\mathrm{s}}{\sigma_{\mathrm{s}}} \text { (non-dimensional) }
\end{aligned}
$$

where $h(m)$ is the deviation of the surface elevation about a mean (32 $\mathrm{km})$ profile and $\mathrm{s}\left(\mathrm{m} \mathrm{km}^{-1}\right)$ is the deviation of surface slope from the mean along the survey line. The mean wind blew downslope at about $30^{\circ}$ to the survey line. The variation with topography

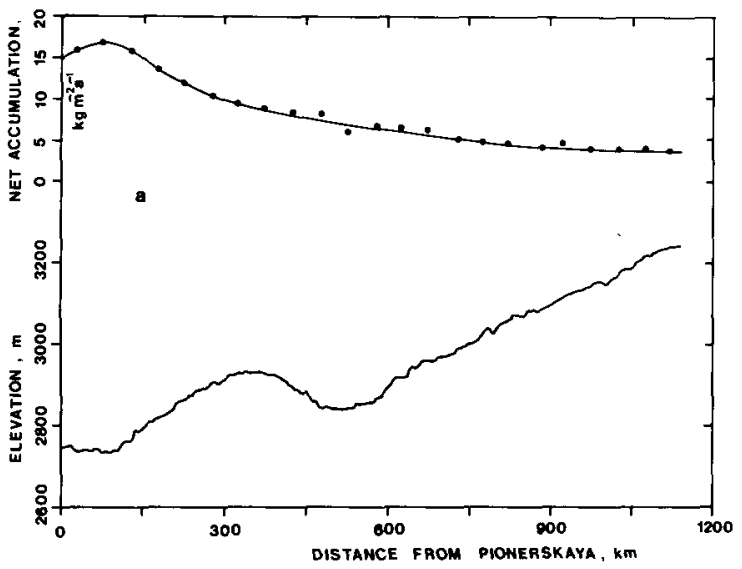

Fig.1(a). Variation of mean net-accumulation rate $(50 \mathrm{~km}$ averages) with distance along the Pionerskaya to Dome $C$ route compared with the surface elevation.

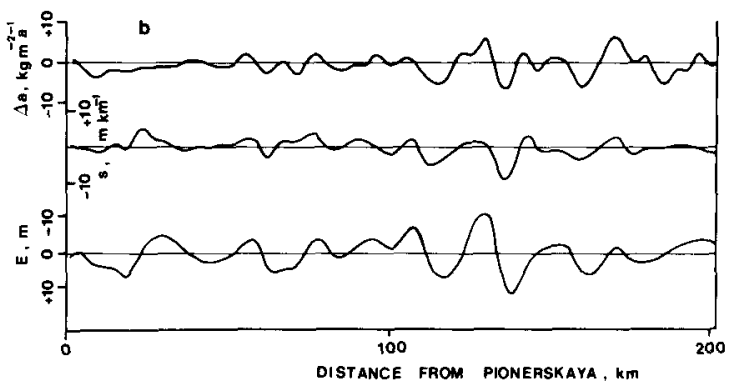

Fig.1(b). Deviations of the mean net accumulation compared to deviations in surface slope and elevation (from $32 \mathrm{~km}$ running means), for the first $200 \mathrm{~km}$ of the profile in Figure 1 a. (Note that the elevation deviations are plotted inverted and a positive slope is downhill towards the left (Pionerskaya), which is roughly the direction of the mean wind. Each curve has been smoothed by $\left.\bar{y}_{i}=1 / 4\left(y_{i-1}+2 y_{j}+y_{j+1}\right)\right)$. 
accounted for $35 \%$ of the variance of the accumulation about the $50 \mathrm{~km}$ means for this test section.

Spatial averaging of accumulation data at scales which do not take account of this variability with local topography could give a misleading view of the pattern. Averaging at discrete $10 \mathrm{~km}$ intervals aliases with the variations caused by local topography with scales of from 5 to $15 \mathrm{~km}$. Averaging at a scale of at least $30 \mathrm{~km}$ and preferably $50 \mathrm{~km}$ is required to present the smooth accumulation distribution over a large area. Temporal variability

A study of the annual increments for the four years from 1977 to 1980 meaned over $50 \mathrm{~km}$ intervals for the Pionerskaya to Dome $C$ line to $670 \mathrm{~km}$ gives a variability of about $40 \mathrm{~kg} \mathrm{~m}^{-2} \mathrm{a}^{-1}$ on annual mean accumulation rates of 63 to $170 \mathrm{~kg} \mathrm{~m}^{-2} \mathrm{a}^{-1}$; $i$.e. from $25 \%$ to over $50 \%$. This can be compared to Bull's (1971) comments that over periods of 5 a temporal variability could greatly exceed $20 \%$.

The temporal variability can be spatially coherent over large distances. The annual increment was substantially above or below the annual mean over intervals of about $200 \mathrm{~km}$ along the Pionerskaya to Dome C line. 1980 was an exceptional year when the accumulation exceeded the mean by about $4 \mathrm{~kg} \mathrm{~m}^{-2} \mathrm{a}^{-1}$ over $650 \mathrm{~km}$ of the line and by about $1.8 \mathrm{~kg} \mathrm{~m}^{-2} \mathrm{a}^{-1}$ over a further $300 \mathrm{~km}$ to Dome $C$, a range of $25 \%$ to $50 \%$ of the mean. In addition about $10 \%$ of individual annual increments showed a non-positive net accumulation with a persistence at a few sites through 2 or $3 \mathrm{a}$. Only one point showed a net loss over $4 \mathrm{a}$.

Pourchet and others (in press) found a $30 \%$

increase in accumulation rate from the 1955-65 decade to the 1965-75 decade for a number of sites covering a large sector of Antarctica. The sites were mainly in the sector from longitude $125^{\circ} \mathrm{E}$, through $180^{\circ}$, to $160^{\circ} \mathrm{W}$, but included James Ross I sland (1 atitude $64^{\circ} \mathrm{S}$ ) in the Antarctic Peninsula, and Vostok and South Pole stations. Cameron (1964) determined the annual accumulation record for the period 1783 to 1956 from stratigraphic studies in a $35 \mathrm{~m}$ deep pit at $\mathrm{S} 2$. The accumulation ranged from 60 to $350 \mathrm{~kg} \mathrm{~m}^{-2} \mathrm{a}^{-1}$ about a mean of $135 \mathrm{~kg} \mathrm{~m}^{-2} \mathrm{a}^{-1}$ with a standard deviation of $46 \mathrm{~kg} \mathrm{~m}^{-2} \mathrm{a}^{-1}$. An inspection of his figure 11 shows that variations of $25 \%$ can be expected between consecutive 10 or 20 a periods.

\section{ACCUMULATION MAP}

The accumulation data are presented in map form in Figure 2. Where possible direct measurements of accumulation, e.g. at stake networks, have been used in the compilation. Results from stratigraphic methods which may contain errors due to subjective interpretation have not been included. The basic data set has been expanded by the inclusion of results from gross $\beta$-activity studies. Where new results from different but parallel stake networks are available, or for different time intervals, both have been included. Smooth isopleths were then drawn through the data. No corrections were applied to stake measurements for snow compaction.

The data are presented as spatial averages of the mean annual net accumulation over nomi nally $100 \mathrm{~km}$ intervals, where available, and over shorter intervals elsewhere. The $100 \mathrm{~km}$ averages convey the same large scale pattern as shorter $50 \mathrm{~km}$ averages. No attempt is made to detail the highly variable coastal region.

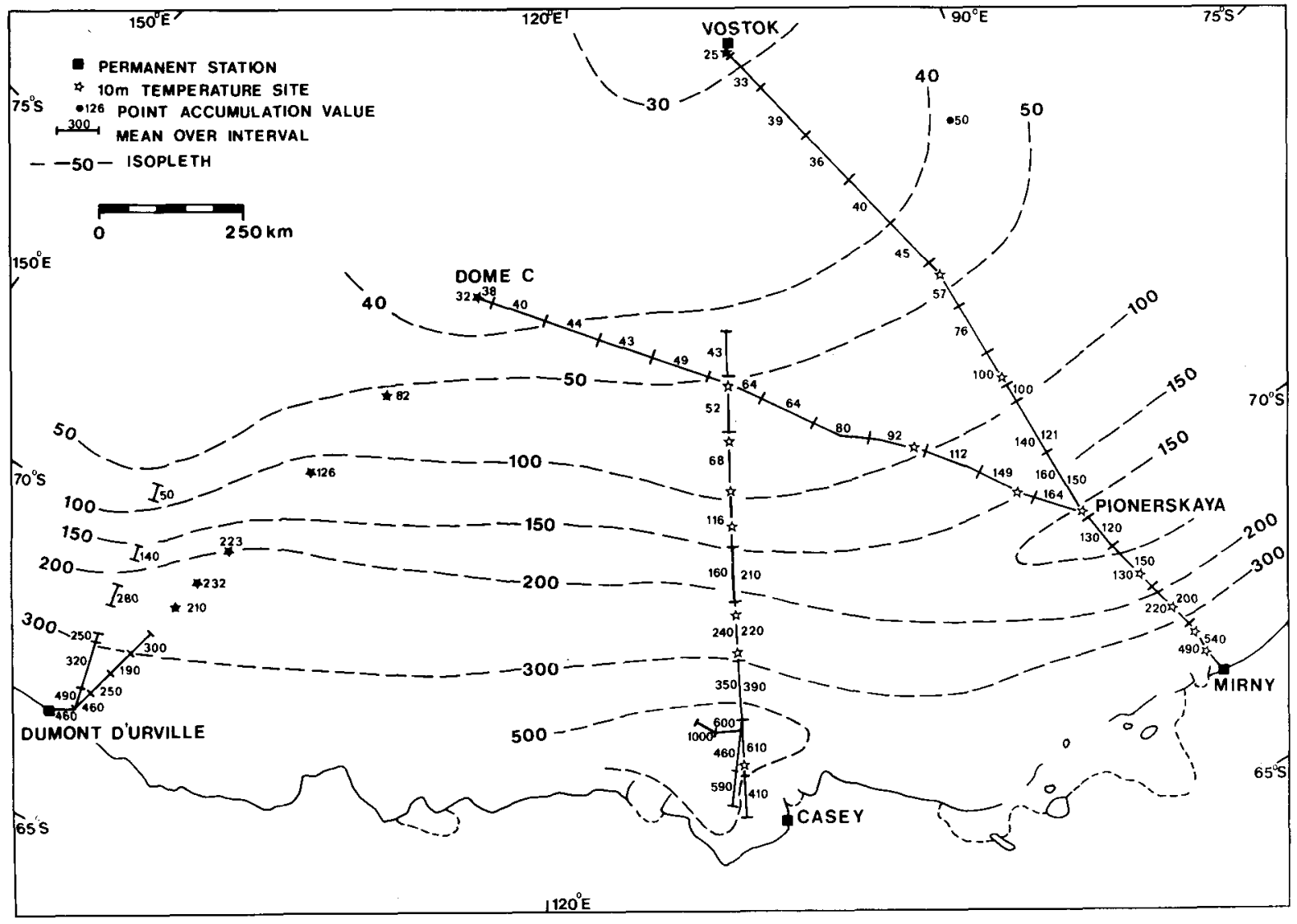

Fig.2. Map of the distribution of mean net accumulation, in $\mathrm{kg} \mathrm{m}^{-2} \mathrm{a}^{-1}$, for the sector $90^{\circ} \mathrm{E}$ to $150^{\circ} \mathrm{E}$. Solid stars represent a $10 \mathrm{~m}$ temperature site and point accumulation value. See Table I for additional $10 \mathrm{~m}$ temperature sites. 


\section{VARIATION OF ACCUMULATION WITH MEAN ANNUAL}

TEMPERATURE

Several authors have considered the variation of accumulation with other parameters. For instance

Loewe (1967) suggested that "the accumulation appears, outside the border regions of Antarctica, rather closely related to the mean annual temperature of the air which is close to the firn temperature at a depth of $10 \mathrm{~m}\left(\theta_{10}\right) "$. He found a $\mathrm{log}-1$ inear relationship:

$\log _{10} 2=2.95+0.0235 \theta_{10}$

(or $\mathrm{a}=981 \exp \left(0.054 \theta_{10}\right) \mathrm{kg} \mathrm{m}^{-2} \mathrm{a}^{-1}$, with $\theta_{10}$ in ${ }^{\circ} \mathrm{C}$ )

for 256 observations of temperature and accumulation. Robin (1977) also considered a similar relationship, but his data (Robin 1977: fig.10) exhibited considerable scatter.

In East Antarctica, many parameters vary in sympathy; for instance temperature and accumulation rate decrease with elevation, latitude and distance from the coast. An inspection of the data indicated that the correlation of accumulation rate with elevation or temperature would account for much of the variation. But for the Pionerskaya to Dome $C$ line the smooth accumulation trend followed temperature very closely (Fig.3). Whereas on the large scale there is

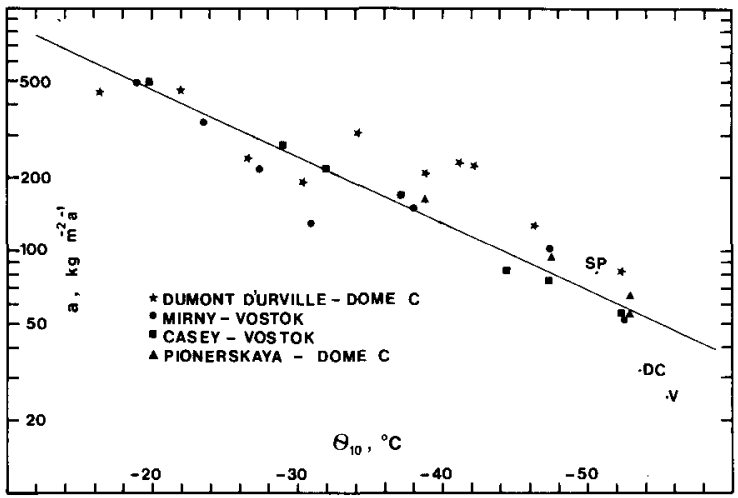

Fig.3. Correlation of mean net-accumulation rate with $10 \mathrm{~m}$ depth snow temperature, which is close to the mean annual air temperature. The line is given by Equation (2) by omitting the stars and individually labelled points DC, V, SP.

a significant variation of over $200 \mathrm{~m}$ in elevation which is not reflected in the accumulation rate pattern (Fig.1). Thus the correlation of accumulation rate with $10 \mathrm{~m}$ depth temperature was chosen for this study.

By restricting consideration to an area with a possibly homogeneous meteorological regime, a better fit can be obtained. Values of $10 \mathrm{~m}$ depth snow temperature and corresponding mean net accumulation are given in Table I. For a selection of 19 sites, contained strictly within the large drainage basin in Wilkes Land, the following relationship is obtained

$$
a=1414 \exp \left(0.060 \theta_{10}(r=0.97)\right. \text {. }
$$

The inclusion of the remaining data increases the scatter (Fig.3), and gives a lower correlation for the following relation:

$$
a=1573 \exp \left(0.062 \theta_{10}(r=0.91)\right. \text {. }
$$

Both relations are clearly significant at the $1 \%$ level, and although accumulation and temperature are determined by meteorological processes, no direct causal relationship is suggested.

The divergence of values for the high-altitude, cold, low-accumulation areas of Dome $C$ and Vostok from the relationship might suggest the dominance of a different controlling process. Accumulation rates at sites 056 to $\mathrm{D} 120$ along the Dumont d'Urville route are high by a factor of 1.5 to 2 , compared to estimates from Equation 2. This would be consistent with a different meteorological regime influencing that area. This simple relationship between accumulation and temperature contrasts with the variations of accumulation with elevation along the Pionerskaya to Dome $C$ route ( $\mathrm{Fig.1}$ ).

\section{CONCLUDING REMARKS}

In determining the mass influx by accumulation to an area on the Antarctic ice sheet, the number and spacing of the sampling sites must be chosen consistent with the aim of the investigation. For small areas $(\sim 1 \mathrm{~km})$ the sampling programme must be sufficient to average out the spatial variability caused by the surface microrelief. For larger areas $(\sim 10 \mathrm{~km}$ and greater) we must be conscious of the variability caused by surface topography on a scale of 5 to $15 \mathrm{~km}$, by sampling over a large network, say $50 \mathrm{~km}$ at $2 \mathrm{~km}$ spacing. In presenting data to illustrate the overall smooth pattern, intervals $(50 \mathrm{~km})$ must be chosen to average out these effects. The close relationship of accumulation with mean annual surface temperature could provide a useful means of interpolation over a homogeneous basin.

Generally, only a short interval of the time series of accumulation is available for any one point. While using the data in mass-budget studies, due account should be taken of the temporal variability in measured net accumulation of 20 to $30 \%$ or more over time intervals of 1 to 20 a or longer. Temporal variability can be apparently coherent over a large area. It would be interesting to know whether the increase or decrease between different periods is due to meteorological events isolated to one area or whether it is indicative of a change over all of Antarctica.

\section{ACKNOWLEDGEMENTS}

The authors are indebted to the many expedition personnel who have contributed to the collection of these data. The work forms a contribution to the International Antarctic Glaciological Project (IAGP) from the work of the Australian National Antarctic Research Expeditions (ANARE), Expéditions Polaires Françaises (EPF), and Sovetskiye Antarkticheskiye Ekspeditsiya (SAE). The support of the US National Science Foundation to some of these operations is also gratefully acknowledged.

\section{REFERENCES}

Barkov N I 1974 Akkumulyatsiya snega na profile Mirny-Vostok $v$ 1970-73 gg [Snow accumulation along the Mirny - Vostok profile in 1970-73]. Materialy Glyatsiologicheskikh Issledovaniy. Khronika. Obsuzhdeniya 24: 255-257

Battye A C Unpublished. Glaciological studies made at Wilkes in 1962. (MSc thesis, University of Melbourne, 1964)

Black H P, Budd W F 1964 Accumulation in the region of Wilkes, Wilkes Land, Antarctica. Journal of Glaciology 5(37): 3-15

Budd WF 1966 Glaciological studies in Liie region of Wilkes, eastern Antarctica, 1961. ANARE Scientific Reports Ser A(IV) GLaciology (Publication 88)

Bu11 C B B 1971 Snow accumulation in Antarctica. In Quam L 0 (ed) Research in the Antarotic. A symposium presented at the Dallas meeting of the American Association for the Advancement of Science ... 1968. Washington, DC, American Association for the Advancement of Science: $367-421$ 
TABLE I. ACCUMULATION AND TEMPERATURE DATA

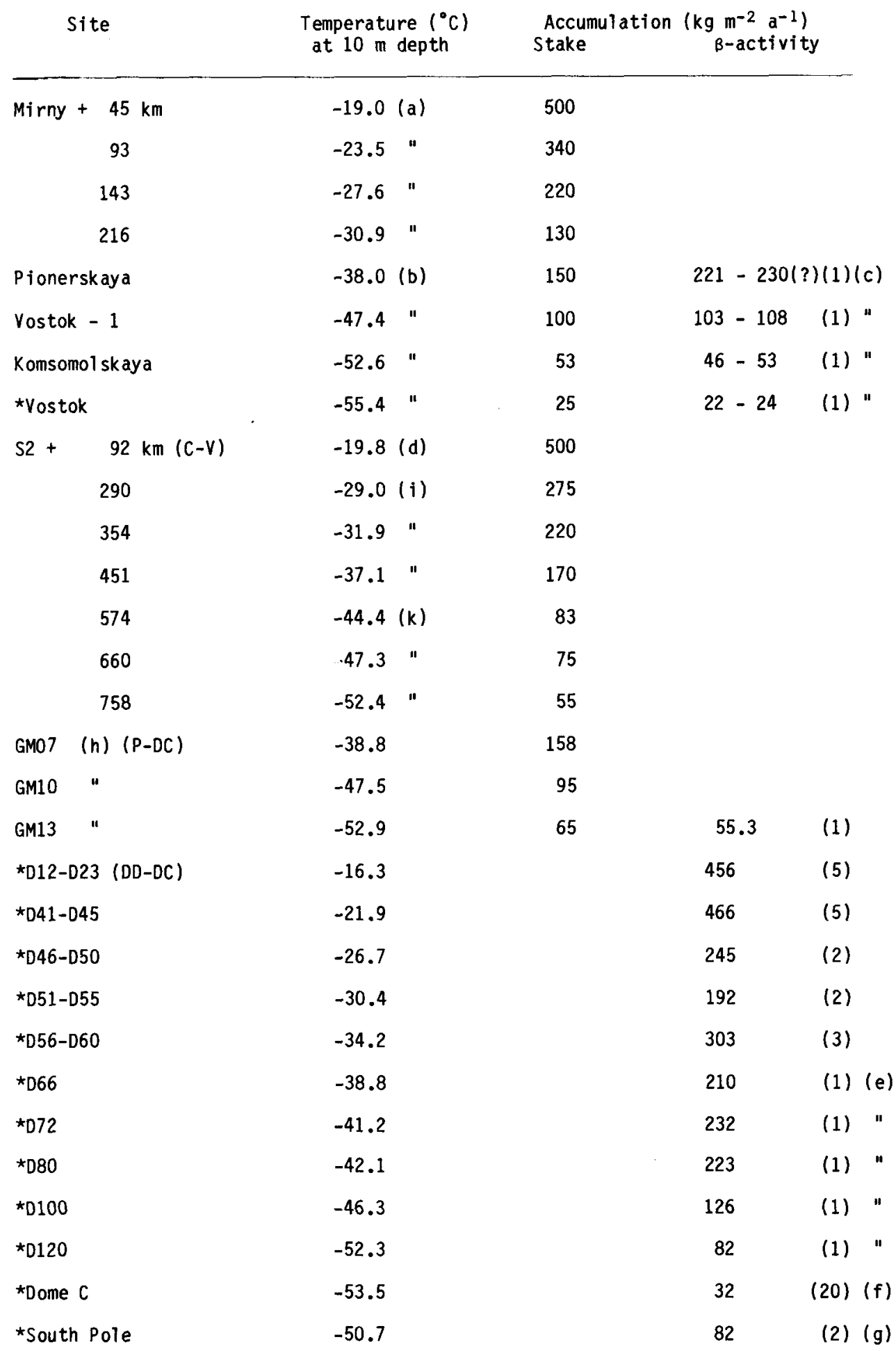

* indicates which values were omitted in the computation for Equation 2,

( ) with number indicates how many values were averaged at the sampling site;

() with letter indicates references in the following list:

a Kartashov (1960)

b Gordiyenko and others (1980)

c Lorius and others (1970)

d Battye (unpublished)

e Lambert and others (1970)

f Petit and others (in press)

$g$ Pourchet and others (in press)

h Young (1979)

i Budd (1966)

$k$ Hamley (personal communication) 
Cameron R L 1964 Glaciological studies at Wilkes station, Budd Coast, Antarctica. In Mellor M (ed) Antarctic snow and ice studies. Washington, DC, American Geophysical Union: 1-36 (Antarctic Research Series 2)

Dyugerov M B, Korolev P A 1980 Kharakter prostranstvennogo raspredeleniya plotnosti snezhnogo pokrova po marshrutu stantsiya Pionerskaya-kupol "C" Espatial distribution character of snow cover density along the Pionerskaya-Dome $C$ traverse route]. Informatsionnyy Byulzeten' Sovetskoy Antarkticheskoy Ekspeditsii 100: 66-69

Gordiyenko F G, Kotlyakov V M, Smirnov K Ye 1980 ob izotopnom i khimicheskom sostave snezhnogo pokrova $v$ vostochnoy Antarktide (po issledovaniyam na profile Mirny-Vostok) [On isotope and chemica] composition of the snow cover of eastern Antarctica (studies along the profile Mirny-Vostok)].

Materialy Glyatsiologicheskikh Issledovaniy. Khronika. Obsuahdeniya 38: 36-49

Kartashov S N 1960 Nekotoryye dannyye o temperaturnom rezhime lednikovogo prokrova Antarktidy [Data on the temperature regime of the ice cover of Antarctica]. Sovetskaya Antarkticheskaya Ekepeditsiya. [Trudy] 10: 107-113

Kotlyakov V M, Barkov N I, Loseva I A, Petrov V N 1974 Novaya karta pitaniya lednikovogo pokrova Antarktidy [New map of the accumulation on the Antarctic ice sheet]. Materialy Glyatsiologicheskikh Issiedovaniy. Khronika. Obsuzhdeniya 24: $248-255$

Lambert G, Ardouin B, Sanak J, Lorius C, Pourchet M 1977 Accumulation of snow and radioactive debris in Antarctica: a possible refined radiochronology beyond reference levels. Intemational Association of Hydrological Sciences Publication 118 (General Assembly of Grenoble 1975 - Isotopes and Impurities in Snow and Ice: 146-158

Loewe F 1967 The water budget in Antarctica. In Nagata $T$ (ed) Proceedings of the symposium on Pacific-Antarctic Sciences. Scientific Reports of the Japanese Antaretic Research Expedition. Special Issue 1: $101-110$

Lorius $C$ In press. Accumulation rate measurements on cold polar glaciers. In Robin $G$ de $Q$ (ed) The climatic record in polar ice sheets. Cambridge, Cambridge University Press

Lorius $C$ and 8 others 1970 Dating of firn layers in Antarctica: application to the determination of the rate of snow accumulation. Intemational Association of Scientific Hydrology Publication 86 (ISAGE) : 3-15

Petit J R, Jouzel J, Pourchet $M$, Merlivat $L$ In press. A detailed study of snow accumulation and stable isotope content in the Dome C (Antarctica). Joumat of Geophysical Research

Pourchet $M$, Pinglot $F$, Lorius $C$ In press. Some meteorological applications of radioactive fallout measurements in Antarctic snows. Joumal of Geophysical Research

Robin G de $Q 1977$ Ice cores and climatic

change. Philosophical Transactions of the Royal Society of London Ser B 280 (972): 143-168

Sheehy $D$ Unpublished. The dynamics of undulating ice flow. (MSc thesis, University of Melbourne, 1981)

Whillans I M 1975 Effect of inversion winds on topographic detail and mass balance on inland ice sheets. Joumal of Glaciology 14(70): 85-90

Whillans I M 1978 Surface mass-balance variability near "Byrd" station, Antarctica, and its importance to ice core stratigraphy. Joumal of Glaciology 20(83): 301-310

Young N W 1979 Measured velocities of interior East Antarctica and the state of mass balance within the I.A.G.P. area. Journal of Glaciology 24(90): 77-87

Young $N$ W, Sheehy D, Hamley T 1982 Ice flow along an IAGP flow line, Wilkes Land, Antarctica. Annals of GLaciology 3: 346 